\title{
Local knowledge of traditional fishermen on economically important crabs (Decapoda: Brachyura) in the city of Conde, Bahia State, Northeastern Brazil
}

Henrique Fernandes de Magalhães ${ }^{1}$, Eraldo Medeiros Costa Neto ${ }^{2 *}$ and Alexandre Schiavetti ${ }^{3}$

\begin{abstract}
Background: This article records the traditional knowledge of crab gatherers in the city of Conde, in the North Coast Region of Bahia State, Northeastern Brazil.

Methods: Data on biological and ecological aspects of economically important brachyuran crustaceans have been obtained from semi-structured interviews and in loco observations conducted from September 2007 to December 2009. A total of 57 fishermen of both genders, aged between 10 and 78 years have been interviewed (individually or collectively) in different contexts; interviewees were asked about aspects such as external morphology, life cycle, trophic ecology, and spatial and temporal distribution of the major economically important brachyuran crustaceans in the region. Seven fishing communities were visited: Siribinha, Sítio do Conde, Poças, Ilha das Ostras, Cobó, Buri and Sempre Viva. Data were analyzed by comparing the information provided by participants with those from the specialized academic literature.
\end{abstract}

Results: The results show that artisanal fishermen have a wide ranging and well-grounded knowledge on the ecological and biological aspects of crustaceans. Crab gatherers of Conde know about growth and reproductive behavior of the animals they interact with, especially with regard to the three major biological aspects: "molt", "walking dance" and "spawning".

Conclusion: This knowledge constitutes an important source of information that should be considered in studies of management and sustainable use of fishery resources in the North Coast Region of Bahia State.

Keywords: Artisanal fishing, Crustaceans, Mangroves, Ethno-ecology

\section{Background}

Mangrove ecosystems are typical of tropical and subtropical regions, in areas influenced by tidal movements [1]. They comprise ecosystemic units with specialized function as they are salinized environment, given the constant inundation by sea water due to the tidal movement. These ecosystems are considered of fundamental ecological importance in their areas of occurrence [2], and as such mangroves should be categorically classified

\footnotetext{
* Correspondence: eraldont@hotmail.com

${ }^{2}$ Biologist, Master of Science in Development and Environment, UFAL, Brazil. $\mathrm{PhD}$ in Ecology and Natural Resources, UFSCar, Brazil. Post-doctoral studies in Ethnoentomology, UNAM, Mexico. Permanent Professor at Universidade Estadual de Feira de Santana, Feira de Santana, Brazil

Full list of author information is available at the end of the article
}

as permanent protected areas since they maintain fish production at adjacent regions and ensure the stabilization of coastal formations. Additionally, two-thirds of the world's fishing communities depend on their existence [3-5].

Crustaceans play a role in the ecosystem dynamics not only by their function in the food chain, but also because some of them - the decapod brachyurans - constantly modify the substrate as they dig holes and bring organic matter from the lower stratum to the surface [6]. Brachyurans are a diverse group and one of the largest biomasses in marine and estuarine environment [7]. These crustaceans are fishery resources of high prestige for human communities inhabiting estuarine zones and the exploitation of these resources provides a livelihood for 
many of them [8-10]. This group of animals is culturally used for various purposes: handicraft $[11,12]$, as a source of income and protein [13-15], in folk medicine [16-18] and in playful activities [11]. Cultural interactions between humans and crustaceans are studied by ethnozoology that, paraphrasing Posey [19], can be defined as the field of ethnobiology that investigates knowledge, classification and methods of use of animals by human societies.

In Bahia State, Northeastern Brazil, fishing activities are especially characterized by familiar work, where all members of the family are directly involved with the collecting and processing of those resources [20]. Specifically in the local mangroves, brachyuran crustaceans are amongst the main wildlife resources that are found and extracted, such as Ucides cordatus (Linnaeus, 1763), Cardisoma guanhumi (Latreille 1825), Goniopsis cruentata (Latreille 1802), and swimming crabs of the family Portunidae. In addition to serving as food, some species are also used for medicine, as craft, and leisure (18).

Considering ethnozoological studies related to crustaceans, there are few works carried out in Bahia State. Costa-Neto [21] has discussed about the ethnobiology and ethnotaxonomy in fishing communities in the municipality of Conde, however fish were the main surveyed animal group; Costa-Neto and Lima (18) studied the local uses of mangrove crustaceans by the inhabitantys of Siribinha beach; Souto [22] carried out an ethnoecological approach of the collecting of Ucides cordatus in Acupe beach; Saraiva [23] recorded some ethnoecological aspects of Macrobrachium carcinus (Linnaeus, 1758) in the city of Camaçari; Magalhães [24] investigated about some brachyurans of economic importance to artisanal fishing communities in the city of Conde.

In the last decades, the northern coast of Bahia State has faced profound political, socio-economic and cultural changes due to their insertion in the global development model, especially due to the expansion of national and international tourism in the region [20]. Consequently, the local landscape and biota have been undergoing changes that have aggravated the existing pressures on ecosystems, thus subjecting the traditional populations to activities with several degrees of impacts generated by the tourism industry [20]. The fishing activity has been gradually replaced by tourism related jobs, what means a progressive loss of knowledge about fishing gear and sustainable management techniques of fishery resources through the generations; that has also negatively reflected on the local fauna and flora [25].

Given the progressive impacts the North Coast region has been suffering over the last decades and considering its socio-cultural and ecological relevance, this study broaches the local knowledge of artisanal fishermen communities in the municipality of Conde by recording biological, ecological and behavioral aspects of economically important brachyuran crustaceans.

\section{Methodology}

As shown in Figure 1, the study area is included in the "Área de Proteção Ambiental Litoral Norte" (Environmental Protection Area of the North Coast), in the city of Conde, more precisely in the estuarine and coastal area of the lower course of Itapicuru River. In its initial stages, the fieldwork was conducted between September 2007 and October 2008, when monthly visits were made to the communities of Siribinha, Poças, Sítio do Conde, Ilha das Ostras, Cobó, Buri and Sempre Viva. In the second stage of the research, two fortnightly visits were made to the three last communities, in the months of February, May and December 2009. When selecting the visitation months, it was sought to consider the two seasons of the year recognized by the fishing communities: "summer" (September-March) and "winter" (April-August), thus correlating the data obtained during the seasons.

Data were recorded by means of semi-structured interviews and through behavioral observations, using the usual ethnographic data collection techniques, following ethnoscientific notions with a balance between emic and etic focused approaches [26]; on the other hand, observations had an ad libitum feature. The questionnaire was approved by the Research Ethics Committee of the State University of Feira de Santana (Comitê de Ética em Pesquisa da Universidade Estadual de Feira de Santana: CEP-UEFS) based on Resolution no. 196/1996 of the National Council of Health, which governs the ethical aspects of research involving humans. A free and informed consent form was read out and made available to those who participated in the study. The aims of the research were explained clearly at the beginning of each interview and those involved were asked whether they would like to participate in the study. The interviews (whether individual or collective) occurred in various contexts, with the participation of 48 men (84.2\%) and 9 women (15.8\%) whose ages ranged between 10 and 78 . The respondents were fishermen of both genders, specialists in gathering mangrove crabs Goniopsis cruentata, swimming crabs (Portunidae), and land crabs Ucides cordatus and Cardisoma guanhumi. They were contacted according to the snowball technique [27], in which a local specialist indicates another one and so on. Women use to go to mangrove forest in order to collect "aratu" G. cruentata and swimming crabs popularly known as "siris", while male fishermen collect land crabs and some (16 of them) are specialized on collecting species of Portunidae. The interviews were recorded using digital recorders and later transcribed for analysis. 


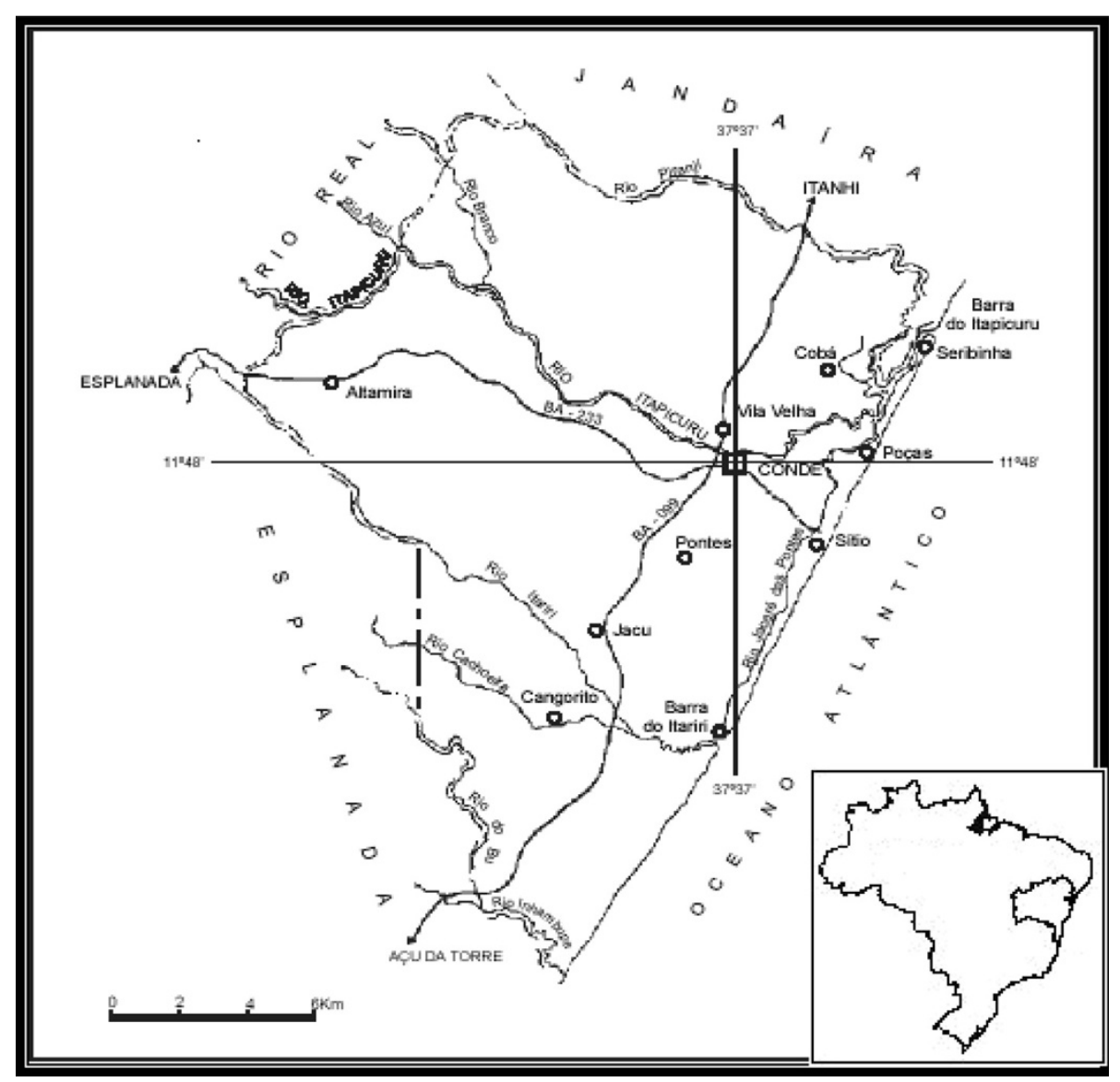

Figure 1 Location of the city of Conde and some of the major fishing communities studied. Adapted from Costa-Neto [18].

Body topography has also been recorded; to this end, cards describing schematic drawings of a land crab [28] and a swimming crab [29] were distributed to the interviewees in order to register the local names they give to the external body structures.

Aiming to observe and collect brachyuran specimens, excursions guided by locals were made to the mangrove. The technique employed during these field trips was the tour [30], i.e., when the researcher follows a path determined by the research participant, which in turn describes what happens. These collections allowed conducting projective tests, which consisted of the presentation of both photographs and visualizations in the natural places of crustacean species, so that the respondents described their perceptions on the biology and ecology of crustaceans.

The data were analyzed using the union model [31]. According to this model, all available information on the surveyed subject is to be considered. Local information provided by the participants was compared with those from the specialized academic literature.
Based on synchronic and diachronic interviews, the controls were performed through verification tests of consistency and validity of responses [31]. All ethnographic material (recordings, transcriptions, field notes and photographs) is stored at the Laboratory of Ethnobiology and Ethnoecology of Universidade Estadual de Feira de Santana, to the attention of the curator of the Ethnozoology Section.

The specimens collected were processed and identified by Professor M. Sc. Cesar Carqueija (Faculdade de Tecnologia e Ciências in Salvador) to the lowest possible taxonomic level, and afterwards stored in the Zoology Museum of the FTC. The record numbers are: Ucides cordatus (MZFTC 5879), Cardisoma guanhumi (MZFTC 5880), Goniopsis cruentata (MZFTC 5881), Callinectes exasperatus (MZFTC 5882), and Callinectes danae (MZFTC 5883). Duplicates were stored in the invertebrate collection of the Zoology Museum of Universidade Estadual de Feira de Santana (MZUEFS) and also in the zoological collection of the Universidade Estadual de Santa Cruz. 


\section{Results and Discussion}

General knowledge about the morphology of brachyuran crustaceans

In the cognitive system of the artisanal fishermen of Conde, were identified three general patterns used in the construction of body topography. They are: polyonomy, i.e., the use of more than one designation to the same body structure; the functionality assigned, which designates functions to the respective structures named; and the anthropomorphic analogy, hence demonstrating the influence of terms of human morphology in the naming of body parts of brachyuran. These same patterns were recorded by Souto [15] during the elaboration of the topography of crustaceans, fishes and mollusks, in a study conducted at the fishing community of Acupe, Bahia.

The external body structures of crustaceans receive designations that reflect how locals perceive these animals. For example, the terms "beard", "arm" and "mouth" are used to designate antennas, chelipeds and chelae, respectively. Fishermen designate specific functions to the structures of the body of brachyuran crustaceans (Table 1). The first pair of pereopods (chelipeds), called "arms" or "spikes", and the chelae, called "mouth" are meant to "get the food". Souto [15] probably attributed the origin of the word "mouth" to a legacy of the early settlers, since the term was already used by Gabriel Soares de Souza in 1587 to designate such structures [32]. In the city of Conde, the term "mouth" was also used to designate the oral cavity of animals, whose function was also related to feeding; probably for that reason, the terms were associated. The remaining pairs of pereopods, called "hams", are used for locomotion ("for walking"). On the other hand, the last pair of legs in swimming crabs (Portunidae) is known as "paddle", in allusion to the structure responsible for the transportation of canoes in the aquatic environment.

Some body structures are used in sexual differentiation, especially the abdomen ("cover") and the chelipeds ("arms" or "spikes"): the male has a narrower abdomen and different sized chelipeds, whereas the female has a longer abdomen and equal sized chelipeds. Body size of crustaceans was also indicated as a criterion for determining sexual dimorphism; in that, males would tend to grow larger than females. Sexual dimorphism observed for land crab (Ucides cordatus) is also determined by the presence of hair in the appendices of males, as noted by these two informants: "The difference is that males have hair on their hands" (Mr. F., 41 years old); "[...]the fingers of males are hairy, different from the females" (R., 29 years). Pinheiro and Fiscarelli [34] and Souto [15] have also reported the use of hair as an indicator of sexual differentiation in $U$. cordatus.

Another criterion used by the fishermen of Conde to distinguish the gender of crabs was the type of track the animals made, which could be either footprints in the mud or feces deposited, whose size and shape allowed determining the gender; the following statements show it clearly:

"As the female is not hairy, its track is narrower than the male's, which is wider" (Mr. N., 44 years old);

"[...] I myself can differentiate them even by their feces. It's because the feces of females are tiny and thick. So, if the feces are like that, it is a female. If it is a long and thin, it is a male" (Mr. N.L., 32 years old).

There may be morphological differences between specimens of the same species, especially with respect to

Table 1 Cognition compared between indigenous and scientific knowledge related to the body topography of economically important brachyurans in the city of Conde

\begin{tabular}{|c|c|c|c|}
\hline Local nomenclature & Scientific nomenclature & Function designated (emic conception) & Function attributed (etic conception) \\
\hline Hull & Carapace & Protect & Protection \\
\hline Beard & Antennas & Orient & Sensorial \\
\hline Eye & Eye & See & Sight \\
\hline Mouth & Mouth & Eat & Food ingestion \\
\hline Chest & Thoracic sternums & Protect what is inside & Exoskeleton \\
\hline Cover & Abdomen & Distinguish males and females & Protection of sexual organs \\
\hline Legs & Pereopods & Walking & Locomotion \\
\hline Joints & Carpus & $\ldots$ & Joint \\
\hline Nail & Dactyl & Holding on the ground & Support on the substrate \\
\hline Arm (gaff) & Cheliped & Defense & Defense \\
\hline Mouth & Chela & Hold food and put it into the mouth & Get food \\
\hline Oar & Pereopod & Swimming & Swimming \\
\hline
\end{tabular}

Sources: Ruppert et al. [7] and Brusca and Brusca [33]. 


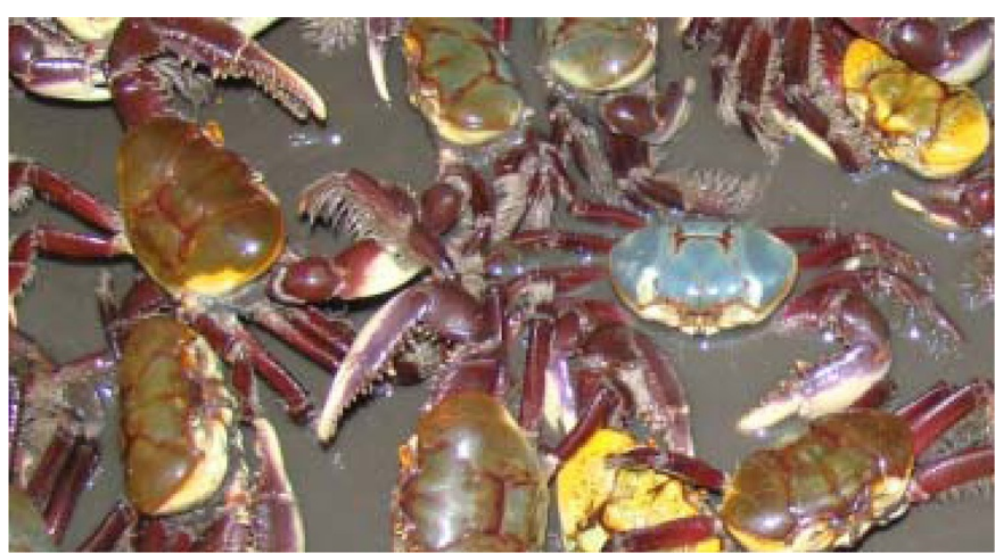

Figure 2 Different color patterns for Ucides cordatus in the fishing community of Sempre Viva, Conde, Bahia State. Photo by Henrique F. de Magalhães.

body color (Figure 2). According to the reports of some people, the major factor that changes the color of $U$. cordatus and Cardisoma guanhumi is the physiognomy of the mangrove where the animal lives; that is confirmed by the following reports: "Much depends on the part of the mangrove where it lives, because there is a drier area in the mangrove. There's a drier area and the crabs living there have another color. Those living in moister areas have different colors" (Mr. N.L., 32 years old). This information is correlated with the concept of Pinto-Coelho [35], which implies that "an ecological unit is the gathering of all organisms, which in turn interacts with the physical environment and is exposed to its influences."

\section{Life Cycle}

Crab gatherers of Conde know about growth and reproductive behavior of the animals they interact with, especially with regard to the three major biological aspects: "molt", "walking dance" and "spawning". Crab ecdysis ("molt") occurs between June and September, a period that, according to local reports, includes winter and early summer. The beginning and the end of the changes directly depends on the tidal movement and the alternation of the lunar cycles; both stages occur during the "low tide", when the mangrove substrate is dry, although it is still wet due to the previous tide. This notion was recorded by Alves and Nishida [5] as it was used by crab gatherers in a mangrove area located at the estuary of the Mamanguape River (Paraíba State). In the same study, the authors have found a significant reduction in the number of "puddles" during "low tide", which they believed to have been due to the fact that the mud was already very hard in that period, thus hindering the excavation of the galleries ("burrows") by crabs. According to the following reports, this finding was also verified in Conde:
"[...] this time of the year they are all puddled because that is to change the hull [...]. It's all puddled. You can go through and see their holes all over there. Then, nobody can catch them at that time. Only in October and November" (Mr. F., 41 years old).

"During the neap tides we get them more often. During neap tides it is better, because the soil is dry, the mud is hard and they cannot dig as much, right? And when the tide is high it becomes harder, because it seems like they sink deeper; as the ground is softer, they sink" (Mr. N., 44 years old).

It is during ecdysis that crabs burrow into the substrate and undergo carapace change. Ecdysis, or "molt", is necessary for crabs to grow, since their exoskeleton is not alive and do not grow with the animal [36]. This phenomenon usually occurs once a year, in adults, and is more commonly observed in young crabs [5], especially when they burrow into individual galleries, under the mangrove trees, at an approximate depth of one meter [37]. Reproduction, behavior, and metabolic processes of many crustaceans are directly affected by the physiology of molt cycle [36]. At that stage, the animals become more fragile and vulnerable to natural predators $[38,39]$. According to Maneschy [40], the crabs become lean and little tasty soon after the change in carapace. This morphological variation in the body of crabs may be evidenced in the following testimonial provided by an artisanal fisherman from the Cobó community: "They are now so short, but when they leave, they are large. So fat, but when it leaves, it is thin. They totally change their bodies" (Mr. F., 41 years old).

The periods of "walking dance" (mating) and spawning of $U$. cordatus and $C$. guanhumi usually cover the 
months from December to March (summer) and occur when the moon is full and the tide starts to "lower". That stage affects the reproductive behavior of these animals, which become disturbed ("Due to the walk, they get "insane' when it is a flooded period", Mrs. E., 72 years old). This phenomenon is not observed for "aratu" (Goniopsis cruentata) and swimming crabs (Portunidae), which, according to local reports are "wanderers by nature", despite spawning occurs in the same period. The following reports exemplify the local knowledge about the "walking dance" behavior:

"In January, the walking dance occurs during high tide. When it drains, they do not leave, because they are reproducing" (L., 13 years).

"He [referring to the aratu crab] is a wanderer by nature, right? They scuttle back and forth. It is not like the other crabs, which have holes. They are constantly walking" (Mrs. L., 34 years old).

"Ii begins in December. From December to March, four walking dances occur when the moon is full" (Mr. E.V., 75 years old).

"When the tide comes at 2 a.m. and it falls three times, it's when they start to walk. No matter if it is day-time, but they prefer the night-time" (Mr. E., 75 years old).

"Walking dance" is a designation used by coastal communities by referring to the behavior of male and female $U$. cordatus as they leave their burrows and walk on the mangrove sediments [41]; this is considered the major reproductive event of the species [42]. Góes et al. [41] have observed that the main reason for this phenomenon is the fact that females need to climb the roots of mangrove trees for egg extrusion (spawning). In other regions, this event is known as "carnaval do caranguejo" ("carnival of the crabs") [38].

According to Sastry [43], crustaceans can reproduce during all months of the year (continuous pattern) or only in the months when environmental conditions are more favorable (discontinuous patterns or seasonal). Brachyurans display an impressive array of reproductive patterns that may be related to environmental factors [44]. Studies by Alcantara-Filho [38] and Costa [45] have described that the reproductive period of Ucides cordatus occurs from December to May. These authors have found that after reproduction in the summer, this crab undergoes ecdysis, with a peak in autumn; on the other hand, females with gonads in maturation process were only found in late winter. According to Hartnoll and Gould [44], this fact corroborates the assertion that growth and reproduction are antagonistic processes that compete for the same resources. Shorter periods have also been described: from January to May [46] and from January to March [47]. Dalabona and Silva [48] mention that studies on the reproductive period have biological importance, especially for commercially exploited species, thus allowing the elaboration of protection laws that contribute to the maintenance of population stocks.

\section{Trophic ecology}

Knowledge of the artisanal fishermen interviewed on the trophic ecology of crabs involves two major aspects: diet composition and food chain they belong to. According to Marques [49], this knowledge is utilitarian, since a cumulative empirical knowledge about the resource/prey leads to a foraging/predating behavior. The following excerpts confirm that this assertion is applicable in Conde:

"I live from fishing. I only make money from fishing" (Mr. F., 41 years old)

"We live here from fishing, right?” (Mr. J., 46 years old).

"It is because fishing is our art, right? We know that because we live here" (R., 29 years old).

According to crab gatherers from Conde, the "uçá" $U$. cordatus and the "gaiamum" C. guanhumi have a very restricted diet that largely consists of leaves and roots of trees that live in the mangrove. Analogue ethnoecological studies have reported similar data $[15,22,50]$. In the community of Acupe (Santo Amaro, Bahia), Souto [22] has also recorded the testimonials of local artisanal fishermen who reported that white mangrove propagules (Laguncularia racemosa) are part of the diet of $U$. cordatus crabs.

Zoological studies on the trophic ecology of crabs, particularly the land crab, indicate that these animals are omnivorous, instead of obligatory herbivorous $[45,47,51,52]$. By analyzing the stomach content of $U$. cordatus in a mangrove forest of Santa Catarina State, Branco [53] has found that $95 \%$ of food was of plant origin, but also some decaying organic matter of animal origin and minerals. This crab plays a role in the trophic web of mangroves, as it collaborates in the processing of the leaves that fall off trees by incorporating their nutrients into the soil and therefore increasing availability of food in the detritivore chain [50,53].

On the other hand, the diet of swimming crabs and Goniopsis cruentata is broader, since it includes vegetable matter (leaves and fruits of mangrove trees) and 
decomposing organic matter, including dead animals. According to Conde's artisanal fishermen, these crustaceans are omnivorous; this knowledge is therefore consistent with information contained in the specialized scientific literature [51,52,54-57]. The following statements make such perception evident:

"They (referring to the Portunidae family crabs) eat the things of the river, fish. They like something more than bad, rotten. Even shrimps may be eaten by them" (R., 29 years old).

"Aratu (eats) dead and rotten things there in the mangrove" (R., 29 years old).

In Armação do Itapocoroy (Penha, Santa Catarina State), Branco and Lunardon-Branco [58] have recorded a diet consisting of 24 items of plant and animal origin for Portunus spinimanus Latreille, 1819 (Portunidae), where crustaceans and fishes were observed to be the most abundant resources. Gaspar [59] asserts that, since the swimming crabs are voracious hunters and insatiable carnivorous, they prefer feeding on decomposing organisms and can digest all organic material; this eating habit (saprozoic) that makes the Portunid crabs major elements in the promotion and maintenance of cleanliness on brackish water areas and beaches.

With respect to the role of "aratu" (G. cruentata) in the trophic web of mangroves, further bio-ecological studies are needed to strengthen this knowledge, including primary herbivory, predation, and exportation of biomass and energy [57].

Based on the information above, it is possible to observe an overlapping of ecological niches among brachyuran decapod crustaceans; such concept refers to the use of the same types of resources by two or more species [60]. Once brachyuran crustaceans share essentially the same area (sympatric), there is also competition among them [61].

As pointed out by artisanal fishermen in the city of Conde, some of the major predators of brachyuran crustaceans in the region are fishes, mammals and humans ("If I am not mistaken, man is the worst of them all", Mr. C., 67 years old). Animals such as raccoons (Procyon cancrivorus Cuvier 1798), otters (Lontra longicaudis Olfers 1818), monkeys and the opossum (Didelphis sp.) are of great importance. These animals and humans can be considered direct competitors within the food chain, since they compete for resources available in the same environment; this can be verified in the following reports:

"There are the raccoon, the opossum. But when the opossum goes in and it cannot exit, then it dies. Not the raccoon. The raccoon strips, puts its arm in and pulls it out" (Mr. E.V., 75 years old).

"This one, there is one we call it otter. So it goes there and drills a hole, right? Then, when we come here, the damage is done. But what can we do? It is the work of nature. They also need to eat, right?"(Mr. A.N., 71 years old).

Nomura [62] has made a collection of reports from folklorists on crab-eating raccoons; Emmons and Feers [63] describe it as an inhabitant of mangroves, which feeds on mollusks, fishes and crabs. The presence of otters in different environments, including mangroves, is directly associated with food availability [64]; besides, their diet preferably consists of fishes, followed by crustaceans, birds, reptiles and small mammals [65].

\section{Spatial and temporal distribution}

The knowledge of fishermen of Conde on the temporal and spatial distribution of brachyuran crustaceans with important role in local economy is closely related to other ecological knowledge regarding these animals, such as migratory flow, habitat types, life cycle, and foraging areas.

There are two major seasons as determinants in the distribution of crabs along mangroves and adjacent areas: "summer" and "winter", which, as pointed out by Marques [31], do not correspond to the official seasons of the annual cycle, but to periods related to the rain and drought. In view of crab gatherers of Conde, summer occurs from September to March, while winter begins in late March and ends in August. In the study by Costa Neto [21], artisanal fishermen of Siribinha (Conde, Bahia) have reported a similar frequency, with summer occurring from mid-August and until the Holy Week period (between the second half of March and the first fortnight of April) and winter starting then and continuing until mid-August. Mourão and Nordi [65] have also found similar information from artisanal fishermen of Mamanguape River estuary (Paraíba), with summer between September and February, when the water begins to "clean up" and winter from March to August.

Fishermen of Conde directly associate the seasonality of brachyuran crustaceans gathered for commercial purposes with the local economic productivity. According to them, summer is generally the most productive season ("For us who live from fishing, summer is wonderful"), except for swimming crabs, which "are more common in the winter", as mentioned in the following excerpts:

"It is available from December to March. After the walking dance, in March, there is a tendency to reduce (Mr. F., 41 years old). 
"Yeah, the swimming crabs can be caught the whole year, but I am quite sure it can be found in winter. In summer it reduces even a hundred percent. On the other hand, the aratu can always be found. But the aratu also reduces in winter because it disappears, right?" (Mr. F., 41 years old).

"The swimming crab can be found all year long, but this time of the year, in August there is a lot of if, but there is not much in summer. It keeps on available, but there is not much" (Mr. E., 75 years old).

The definition and perception of these two major seasons are associated with the understanding of gatherers of Conde on the variations of water salinity in mangroves, which causes changes in the spatial distribution of species and consequently seasonal variations; the following testimonials corroborate that:

"The land crab (referring to Ucides cordatus) can be more easily found in December. I think it is because of the time, right?" (Mr. E., 75 years old).

"The swimming crabs depend on the flooding. At that time, the river flow drags them to the sea. When the water starts to get salty, they all come back to the river" (Mr. R., 66 years old).

According to Posey [66], the spatial distribution of crabs is expressed by artisanal fishermen of Conde as major ecological zones or "ecozones". The author has defined "ecozones" as ecological areas where resources can be found and recognized in other cultural systems that may or may not coincide with those scientific typologies. The major ecological zones observed in Conde are locally known as "mangrove", "river" and "marsh". The land crab ( $U$. cordatus), the blue crab (Callinectes exasperates, Callinectes danae) and the mangrove crab (G. cruentata) are the crustaceans of the "mangrove"; the other swimming crabs inhabit the "river", whereas the "marsh" is the habitat of "gaiamum" crabs. Within a single "ecozone", there are different areas of distribution of faunistic resources. Thus, for example, $U$. cordatus lives "holed up" ("under the mud"), in holes whose depths are approximately a hundred or a hundred and twenty centimeters, according to the locals ("It is approximately one hundred and twenty centimeters deep", Mr. J., 46 years old); G. cruentata lives in "stock hollows" or "mangrove swamps", although it may occasionally invade the burrows of $U$. cordatus when the tides are "neap"; in turn, the blue crab inhabits the banks of the rivers that flow through the mangrove, although it can be also found "holed up". Yet, these spatial distributions may change occasionally; as an example, the "gaiamum" crabs may leave their burrows in the "marshes" and move to the mangroves (according to local reports, it is rare though) when the "ground is hard". The following testimonials corroborate this information:

“The uçá ( $U$. cordatus) lives hidden in the mud. The swimming crabs can also be found in burrows. The "aratu" sometimes gets in, but they are often found in stock hollows. Those old mangrove woods that are hollow, they go there, and go inside them" (R., 29 years old).

"The difference is that the "gaiamum" crab survives in the dry places, it lives in the bushes. It also uses water, right? Because no one can live without water, but it moves about the dry too" (R., 29 years old).

The identification of ecological zones in fishing communities is a fairly common practice [22,37,65,67-69]. In a survey on the bio-ecological aspects of mangrove brachyuran in Itacorubi (Florianópolis-SC), Branco [70] has recorded a greater abundance of swimming crabs in the mouths of rivers that flow through the mangrove swamps, canals and streams, with peaks in spring and summer, while G. cruentata was widely found in the soil of intertidal zones and edges of rivers and canals where it builds burrows along the mangrove roots (peaks in summer); on the other hand Cardisoma guanhumi were more frequently observed in "apicum" ("salty water marshes"), where they build burrows above the high tide mark, with predominance in spring; finally, Ucides cordatus was more abundant in intertidal and infratidal zones, where they preferred to dig burrows due to lower variation in water salinity [71], also predominantly in spring. A subsequent study made by Branco [53], in the same mangrove, has recorded variations ranging from 90 to $180 \mathrm{~cm}$, with an average depth of $120 \mathrm{~cm}$ in the burrows built by $U$. cordatus, depending on the area and the season; also, a higher average number of burrows per square meter was observed in the sandy bottom shoreline, which was directly related to fluctuations in water salinity in the burrows.

\section{Conclusion}

Artisanal fishermen of Conde have an established knowledge on biological and ecological aspects related to brachyuran crustaceans of economic importance in the region, as well as the environment where they live, which covers the external morphology, life cycle associated with tidal dynamics, reproduction, trophic ecology and spatial and temporal distribution. Much of this knowledge is supported by data from the specialized scientific literature.

Although the creation of the Marine Extractive Reserve, a sort of marine protected area, IUCN category VI, to preserve both scenarios environmental and socio-cultural 
region of Earl is still a future possibility, this study, and other ethnobiological to be performed, should be used for ordering the management of local resources. In the case of the use of the crustaceans by local communities, the establishment of rules of use to the zones identified - "mangrove", "river" and "marsh" should be incorporated into the protected area management, ensuring the sustainability of the resource and recognizing traditional knowledge.

With this interaction ensures the perpetuation of social local way of life and biodiversity conservation on the north coast of Bahia.

\section{Competing interests}

The authors declare that they have no competing interests.

\begin{abstract}
Author details
${ }^{1}$ Biologist, Master of Science in Applied Zoology, Universidade Estadual de Santa Cruz, Ilhéus, Brazil. 'Biologist, Master of Science in Development and Environment, UFAL, Brazil. PhD in Ecology and Natural Resources, UFSCar, Brazil. Post-doctoral studies in Ethnoentomology, UNAM, Mexico. Permanent Professor at Universidade Estadual de Feira de Santana, Feira de Santana, Brazil. ${ }^{3}$ Ecologist. Master of Science in Environment Engineering Sciences, USP, Brazil. PhD in Ecology and Natural Resources, UFSCar, Brazil. Full Professor at Universidade Estadual de Santa Cruz, Ilhéus, Brazil.
\end{abstract}

\section{Authors' contributions}

HFM carried out the field research and drafted the manuscript. EMCN participated in its design and coordination, and helped to draft the manuscript. AS helped to draft the manuscript. All authors read and approved the final manuscript.

Received: 22 June 2011 Accepted: 26 March 2012

Published: 26 March 2012

\section{References}

1. Cintrón G, Schaeffer-Novelli Y: Introducción a la ecología del manglar Montevideo, UNESCO/ROSTLAC 1983.

2. Oliveira LAK, Freitas RR, Barroso GF: Manguezais: turismo e sustentabilidade. Cadernos Virtual de Turismo 2005, 5:51-56.

3. FAO: Status and trends in mangrove area extent worldwide. By Wilkie, M.L. and Fortuna, S. Forest Resources Assessment Working Paper No. 63. Forest Resources Division. FAO, Rome 2003.

4. Wielgus, J., E. Cooper, R. Torres and L. Burke. 2010. Coastal Capital: Dominican Republic. Case studies on the economic value of coastal ecosystems in the Dominican Republic. Working Paper. Washington, DC: World Resources Institute. Available online at http://www.wri.org/ coastal-capital.

5. Alves RRN, Nishida AK: A ecdise do caranguejo-uçá, Ucides cordatu L. (Decapoda, Brachyura) na visão dos caranguejeiros. Interciencia 2002, 27:110-117.

6. Aveline LC: Fauna dos manguezais brasileiros. Revista Brasileira de Geografia 1980, 42:786-821

7. Ruppert EE, Fox S, Barnes RD: Zoologia dos invertebrados: uma abordagem funcional-evolutiva São Paulo: Roca. 2005.

8. Schaeffer-Novelli Y: Manguezal: ecossistema entre a terra e o mar São Paulo: Caribbean Ecological Research 1995.

9. Jankowsky M, Pires JSR, Nordi N: Contribuição ao manejo participativo do caranguejo-uçá, Ucides cordatus (L., 1763), em Cananéia, SP. Boletim do Instituto de Pesca 2006, 32:221-228.

10. Nascimento DM, Mourão JS, Rocha PD, Ferreira EM, Bezerra DM: Impactos sócio-ambientais provocados pela técnica "redinha" na captura do caranguejo-uçá Ucides cordatus no estuário do Rio Mamanguape (PB). Resumos do IX Encontro de Biologia da UEFS; IV Encontro Nordestino de Etnoecologia e Etnobiologia: 2008; Feira de Santana: Universidade Estadual de Feira de Santana 2008, 34.

11. Cascudo LC: Dicionário do folclore brasileiro Rio de Janeiro: Ediouro 1972.

12. Farias MF, Rocha-Barreira CA: Conchas de moluscos no artesanato cearense Fortaleza: Nave 2007
13. Reitermajer D: Comunidade extrativista do manguezal de Porto Sauipe, Entre Rios-BA: uma abordagem ecológica e social. Salvador: Monografia Universidade Federal da Bahia; 1996.

14. Nomura H: Os crustáceos na cultura popular Mossoró: Fundação Vingt-Un Rosado 2001.

15. Souto FJB: A ciência que veio da lama. Uma abordagem etnoecológica abrangente das relações ser humano/manguezal na comunidade pesqueira de Acupe, Santo Amaro-BA. Tese Universidade Federal de São Carlos, São Carlos, 2004

16. Lages-Filho J: A medicina popular em Alagoas Salvador: Instituto Nina Rodrigues 1934.

17. Magalhães J: Medicina folclórica Fortaleza: Imprensa Universitária do Ceará 1966.

18. Costa-Neto EM, Gordiano-Lima KL: Contribuição ao estudo da interação entre pescadores e caranguejos (Crustacea, Decapoda, Brachyura): considerações etnobiológicas em uma comunidade pesqueira do Estado da Bahia, Brasil. Actualidades Biológicas 2000, 22:195-202.

19. Posey DA: Etnobiologia: teoria e prática. Suma Etnológica Brasileira. Etnobiologia. Petrópolis: Vozes. Ribeiro D 1986,15-25.

20. Costa-Neto EM: A cultura pesqueira do litoral norte da Bahia: etnoictiologia, desenvolvimento e sustentabilidade Salvador: EDUFBA 2001.

21. Costa-Neto EM: Etnoictiologia, desenvolvimento e sustentabilidade no litoral norte baiano. Thesis Universidade Federal de Alagoas, Maceió: Um estudo de caso entre pescadores do município de Conde. Msc; 1998.

22. Souto FJB: Uma abordagem etnoecológica da pesca do caranguejo, Ucides cordatu, Linnaeus, 1763 (Decapoda: Brachyura), no manguezal do distrito de Acupe (Santo Amaro - BA). Biotemas 2007, 20:69-80.

23. Saraiva RS: Aspectos etnoecológicos da pesca do pitu, Macrobrachium carcinus, Linnaeus, 1758 (Decapoda; Palaemonidae), no Rio Pojuca (Distrito de Barra do Pojuca, Camaçari - BA). Monografia (Licenciatura em Ciências Biológicas), Universidade Católica do Salvador, Salvador, 2008.

24. Magalhães HF: Etnoecologia de crustáceos (Decapoda: Brachyura) segundo os pescadores artesanais do município de Conde, litoral norte do Estado da Bahia. Thesis, Universidade Estadual de Santa Cruz, Ilhéus: Msc; 2009.

25. Costa-Neto EM, Andrade CTS, Couto DF, Magalhães HF, Mascarenhas LS, Campos EVM: Diagnóstico etnoecológico em comunidades pesqueiras do município de Conde, região Litoral Norte do Estado da Bahia. Novos olhares para o desenvolvimento regional sustentável: caminhos e perspectivas. Santa Cruz do Sul: EDUNISC Costa-Neto EM, Santos FM, Londero JC 2010, 20-52.

26. Sturtevant WC: Studies in ethnoscience. American Anthropologist 1964, 66:99-131.

27. Goodman LA: Amostragem bola de neve. Annals of Mathematics and Statistics 1961, 32:148-170.

28. Fiscarelli AG, Pinheiro MAA: Perfil sócio-econômico e conhecimento etnobiológico do catador de caranguejo uçá, Ucides cordatu (Linnaeus, 1763) nos manguezais de Iguape (24; 41' S), SP, Brasil. Actualidades Biológicas 2002, 24:129-142.

29. Narchi W: Crustáceos: estudos práticos São Paulo: Polígono; EDUSP 1973.

30. Spradley JP, McCurdy DW: The cultural experience: ethnography in complex society Tennessee: Kingsport Press of Kingsport 1972.

31. Marques JGW: Aspectos ecológicos na etnoictiologia dos pescadores do Complexo Estuarino-Lagunar Mundaú-Manguaba. Campinas, Campinas: Alagoas. Thesis Universidade Estadual de Campinas; 1991.

32. Souza GS: Tratado descritivo do Brasil em 1587 Recife: Massangana 2000.

33. Brusca RC, Brusca GJ: Invertebrados Rio de Janeiro: Guanabara Koogan 2007.

34. Pinheiro MAA, Fiscarelli AG: Manual de apoio à fiscalização do caranguejo-uçá (Ucides cordatus) Itajaí: CEPSUL/IBAMA 2001.

35. Pinto-Coelho RM: Fundamentos em ecologia Porto Alegre: Artes Médicas Sul 2000.

36. Hickman CP, Roberts LS, Larson A: Integrated principles of zoology New York: McGraw-Hill 2001.

37. Nordi N: A captura do caranguejo-uçá (Ucides cordatu) durante o evento reprodutivo da espécie: o ponto de vista dos caranguejeiros. Revista Nordestina de Biologia 1994, 9:41-47.

38. Alcântara-Filho P: Contribuição ao estudo da biologia e ecologia do caranguejo-uçá, Ucides cordatu (L., 1763) (Crustacea, Decapoda, Brachyura), no manguezal do Rio Ceará (Brasil). Arquivos de Ciências Marinhas 1978, 18:1-41.

39. Nascimento AS: Biologia do caranguejo-uçá Ucides cordatus Aracaju: ADEMA 1993.

40. Maneschy MC: Pescadores nos manguezais: estratégias técnicas e relaçōes sociais de produção na captura de caranguejo. Povos das águas: realidade e 
perspectivas na Amazônia Belém: MCT/CNPq Furtado LG, Leitão W, Fiúza A 1993, 19-62.

41. Góes JM, Fernandes-Góes LC, Legat JFA: "Andada" do caranguejo Ucides cordatus (Linnaeus, 1763) (Crustacea, Ocypodidae) na Área de Proteção Ambiental (APA) do Delta do Parnaíba, Piauí. Resumos do 15; Encontro de Zoologia do Nordeste 2005. Salvador: UFBA 2005, 217.

42. Nordi N: A produção dos catadores de caranguejo-uçá (Ucides cordatu) na região de Várzea Nova, Paraíba, Brasil. Revista Nordestina de Biologia 1994, 9:71-77.

43. Sastry AN: Ecological aspects of reproduction. The biology of Crustacea. Vol. 8. Environmental adaptations. New York: Academic Press Bliss DE, Vernberg FJ, Vernberg WB 1983, 179-270.

44. Hartnoll RG, Gould P: Brachyuran life history strategies and the optimization of egg production. Symposium of the Zoological Society of London 1988, 59:1-9.

45. Costa RS: Biologia do caranguejo-uçá, Ucides cordatu (Linnaeus, 1763) Crustáceo, decápode - no Nordeste brasileiro. Boletim Cearense de Agronomia 1979, 20:1-74

46. Mota-Alves MI: Sobre a reprodução do caranguejo-uçá, Ucides cordatu (Linnaeus), em mangues do Estado do Ceará (Brasil). Arquivos de Ciências Marinhas 1975, 15:85-91.

47. Castro ACL: Aspectos bio-ecológicos do caranguejo-uçá, Ucides cordatus cordatu (Linnaeus 1763), no estuário do rio dos Cachorros e estreito do Coqueiro, São Luís - MA. Boletim do Laboratório de Hidrobiologia 1986, 7:7-27.

48. Dalabona G, Loyola-Silva J: Período reprodutivo de Ucides cordatu (Linnaeus) (Brachyura, Ocypodidae) na Baía das Laranjeiras, sul do Brasil. Acta Bioloógica Paranaense 2005, 34:115-126.

49. Marques JGW: Pescando pescadores: ciência e etnociência em uma perspectiva ecológica São Paulo: NUPAUB/Fundação Ford 2001.

50. Paiva MP, Bezerra RCF, Fonteles-Filho AA: Tentativa de avaliação dos recursos pesqueiros do Nordeste brasileiro. Arquivos de Ciências Marinhas 1971, 11:1-43.

51. Leitão SN, Schwamborn R: Interações tróficas no canal de Santa Cruz. Gerenciamento participativo de estuários e manguezais. Recife: EDUFPE Barros HM, Eskinazi-Leça E, Macedo SJ 2000, 163-180.

52. Nordhaus I, Wolff M, Diele K: Litter processing and population food intake of the mangrove crab Ucides cordatu in a high intertidal forest in northern Brazil. Estuarine and Coastal Shelf Science 2006, 67:239-250.

53. Branco JO: Aspectos bioecológicos do caranguejo Ucides cordatu (Linnaeus, 1763) (Crustacea, Decapoda) do manguezal do Itacorubi, Santa Catarina, BR. Arquivos de Biologia e Tecnologia 1993, 36:133-148.

54. Branco JO, Verani JR: Dinâmica da alimentação natural de Callinectes dana Smith (Decapoda, Portunidae) na Lagoa da Conceição, Florianópolis, Santa Catarina, Brasil. Revista Brasileira de Zoologia 1997, 14:1003-1018.

55. Petti MAV: Papel dos crustáceos braquiúros na rede trófica da plataforma interna de Ubatuba, São Paulo (Brasil). Neritica 1997, 11:123-137.

56. Carqueija CRG, Gouvêa EP: Hábito alimentar de Callinectes larvatu Ordway (Crustacea, Decapoda, Portunidae) no manguezal de Jiribatuba, Baía de Todos os Santos, Bahia. Revista Brasileira de Zoologia 1998, 15:273-278.

57. Gonçalves $P$, Rosa EA, Minnie KY: Estimativa populacional do caranguejo estuarino Goniopsis cruentata no manguezal de Ratones, Florianópolis, SC. Semana de Ensino, Pesquisa e Extensão da UFSC. Florianópolis: UFSC 2007.

58. Branco JO, Lunardon-Branco MJ: Ecologia trófica de Portunus spinimanu Latreille, 1819, na Armação do Itacoporoy, Penha, Santa Catarina. Revista Brasileira de Zoologia 2002, 19:723-729.

59. Gaspar MH: Contribuição ao estudo biológico do "siri" Callinectes danae Smith 1869 (Decapoda: Portunidae) do rio Itiberê (Paranaguá-PR). Universidade Federal do Paraná, Curitiba: Msc. Thesis; 1981

60. Nogueira-Ferreira FH, Augusto SC: Amplitude de nicho e similaridade no uso de recursos florais por abelhas eussociais em uma área de cerrado. Bioscience Journal 2007, 23:45-51.

61. Pinheiro MMA, Fransozo A, Negreiros-Fransozo ML: Dimensionamento e sobreposição de nichos dos portunídeos (Decapoda, Brachyura), na Enseada da Fortaleza, Ubatuba, São Paulo, Brasil. Revista Brasileira de Zoologia 1997, 14:371-378.

62. Nomura H: Os mamíferos no folclore Mossoró: Fundação Vingt-Un Rosado 1996.

63. Emmons LH, Feers F: Neotropical rainforest mammals. A field guide Chicago: The University of Chicago Press; 1990.

64. Carvalho JO, Barbosa C, Tosatti M: Caracterização da dieta alimentar da Lontra longicaudis em um ambiente marinho, Praia de Naufragados, Itha de
Santa Catarina, SC-Brasil. Resumos do IV Congresso Integrado de Iniciação Científica, 2005. Rio do Sul: UNIDAVI 2005, 32

65. Mourão JS, Nordi N: Pescadores, peixes, espaço e tempo: uma abordagem etnoecológica. Interciencia 2006, 31:358-363.

66. Posey DA: Etnobiologia e ciência de fol: sua importância para a Amazônia. Tübinger Geographische Study 1987, 95:95-108.

67. Cordell J: The lunar-tide fishing cycle in Northeastern Brazil. Ethnology 1974, 13:379-392.

68. Robben ACGM: Sea tenure and conservation of coral reef resources in Brazil. Cultural Survival Quarterly 1985, 9:45-47.

69. Mourão JS: Classificação e ecologia de peixes estuarinos por pescadores do estuário do rio Mamanguape - PB. PhD Thesis Universidade Federal de São Carlos. São Carlos 2000

70. Branco JO: Aspectos ecológicos dos Brachyura (Crustacea: Decapoda) no manguezal do Itacorubi, SC, Brasil. Revista Brasileira de Zoologia 1991, 7:165-179.

71. Soriano-Sierra EJ, Macedo-Silva JRB, Derner RB, Branco JO: Aspectos ecológicos do Manguezal de Itacorubí, Santa Catarina, Brasil. Ecologia e Gerenciamento do Manguezal de Itacorubí Florianópolis: NEMAR/CCB/UFSC, SDM/FEPEMA. Soriano-Sierra EJ, Sierra de Ledo B 1998, 115-138.

doi:10.1186/1746-4269-8-13

Cite this article as: Magalhães et al:: Local knowledge of traditional fishermen on economically important crabs (Decapoda: Brachyura) in the city of Conde, Bahia State, Northeastern Brazil. Journal of Ethnobiology and Ethnomedicine 2012 8:13.

\section{Submit your next manuscript to BioMed Central and take full advantage of:}

- Convenient online submission

- Thorough peer review

- No space constraints or color figure charges

- Immediate publication on acceptance

- Inclusion in PubMed, CAS, Scopus and Google Scholar

- Research which is freely available for redistribution 